\title{
Analisa Sistem EDOM Politeknik Negeri Jakarta Menggunakan Technology Acceptance Model (TAM)
}

\author{
Farhan Fadli Dzil Ikram, Ninda Komala, Toriq Wahid Syaefullah \\ Jurusan Teknik Informatika dan Komputer PNJ \\ Depok \\ farhan.ikram.tik14@mhsw.pnj.ac.id, ninda.komala.tik14@mhsw.pnj.ac.id, toriq.syaefullah.tik14@mhsw.pnj.ac.id
}

Diterima: 13 Maret 2018. Disetujui 15 April 2018. Dipublikasikan Mei 2018

\begin{abstract}
Abstrak - Penelitian ini dilakukan untuk mengetahui prediksi keyakinan mahasiswa Politeknik Negeri Jakarta serta menganalisis pemanfaatan fasilitas EDOM dengan metode pendekatan model Techonology Acceptance Model (TAM), di mana variabel yang dianalisis adalah Perceived Ease of Use (PEU), Perceived Usefulness (PU), Attitude Toward of Using (ATU), dan Behavioral Intention of Use (ITU) di mana respondennya adalah mahasiswa Politeknik Negeri Jakarta. Dalam pengambilan sampel dilakukan dengan teknik simple random sampling. Dimana tahap pengujian dilakukan dengan uji validitas, dan uji realiabilitas terhadap variabel PEU dan PU. Hasil yang diharapkan adalah dari variabel independen sample test signifikan untuk menentukan tingkat prediksi keyakinan mahasiswa.
\end{abstract}

Kata Kunci: evaluasi dosen, SQA, metode TAM.

\section{PENDAHULUAN}

Evaluasi merupakan salah satu rangkaian kegiatan dalam meningkatkan kualitas, kinerja, atau produktifitas suatu lembaga dalam melaksanakan programnya. Fokus evaluasi adalah individu, yaitu prestasi belajar yang dicapai kelompok atau kelas. Melalui evaluasi akan diperoleh informasi tentang apa yang telah dicapai dan apa yang belum dicapai. Selanjutnya, informasi ini digunakan untuk perbaikan suatu program. Menurut Arikunto dan Cepi [1] evaluasi adalah kegiatan untuk mengumpulkan informasi tentang bekerjanya sesuatu, yang selanjutnya informasi tersebut digunakan untuk menentukan alternatif yang tepat dalam mengambil sebuah keputusan. Fungsi utama evaluasi dalam hal ini adalah menyediakan informasi-informasi yang berguna bagi pihak decision maker untuk menentukan kebijakan yang akan diambil berdasarkan evaluasi yang telah dilakukan.

Salah satu evaluasi yang biasa dilakukan yaitu evaluasi dosen. Di akhir semester, di setiap Perguruan Tinggi telah umum dilakukan proses evaluasi dosen untuk mengetahui pengaruh pengajaran dosen terhadap mahasiswa. Pengajaran yang baik tentunya akan sangat membantu mahasiswa untuk mencapai pembelajaran yang baik. Kualitas pengajaran dan standar akademik tentunya perlu untuk selalu dievaluasi dan ditingkatkan karena pendidikan tinggi merupakan kegiatan yang cukup penting. Pengajaran yang baik merupakan hal yang sulit dan kompleks, sangat individual dan berkaitan dengan materi. Pada dasarnya, evaluasi dosen digunakan untuk mengidentifikasi kontribusi dosen dalam pencapaian tujuan program studi dan menilai kebutuhan dosen akan bimbingan dan pelatihan dalam bidang pengajaran tertentu.

Saat ini Politeknik Negeri Jakarta memiliki sistem EDOM yang digunakan untuk melakukan penilaian terhadap kinerja dosen. Namun untuk mengetahui tingkat penerimaan sistem EDOM yang digunakan di Politeknik Negeri Jakarta bisa dianalisa dengan menggunakan model Technology Acceptance Model (TAM). TAM merupakan analisis yang digunakan untuk mengetahui sikap penerimaan pengguna terhadap hadirnya teknologi. Konsep TAM dikembangkan oleh Davis [2] yang menawarkan sebuah teori sebagai landasan untuk mempelajari dan memahami perilaku pemakai dalam menerima dan menggunakan sistem informasi. Model TAM yang dikembangkan Davis ini telah dimodifikasi dengan lima konstruk, lima konstruk tersebut ialah persepsi tentang kemudahan penggunaan (Perceived Ease of Use), persepsi terhadap kemanfaatan (Perceived Usefulness), sikap terhadap penggunaan (Attitude Toward Using), perilaku untuk tetap menggunakan (Behavioral Intention to Use), dan kondisi nyata penggunaan sistem (Actual System Usage). [3] 
Untuk itu pada penelitian ini akan dilakukan identifikasi dan analisa mengenai berbagai faktor yang mempengaruhi pengguna untuk menerima atau menggunakan sistem EDOM dengan menggunakan model TAM. Dengan mengetahui penerimaan sistem EDOM di PNJ akan menjadi rekomendasi untuk pihak PNJ untuk meningkatkan efektivitas dan layanan sehingga menjadi salah satu sistem yang dapat memenuhi kebutuhan mahasiswa PNJ.

\section{TINJAUAN PUSTAKA}

\section{A. Sistem Menurut Sutarman [1]}

Sistem adalah kumpulan elemen yang saling berinteraksi dalam suatu kesatuan untuk menjalankan suatu proses pencapaian suatu tujuan utama. Menurut Jogiyanto [2] sistem dapat didefinisikan dengan pendekatan prosedur dan dengan pendekatan komponen. Menurut Jimmy L.Goal [4] sistem adalah hubungan satu unit dengan unit-unit lainnya yang saling berhubungan satu sama lainnya dan yang tidak dapat dipisahkan serta menuju satu kesatuan dalam rangka mencapai tujuan yang telah ditetapkan. Apabila suatu unit macet atau terganggu, unit lainnya pun akan terganggu untuk mencapai tujuan yang telah ditetapkan tersebut.

Berdasarkan dari definisi-definisi diatas dapat disimpulkan bahwa sistem merupakan kumpulan rangkaian yang saling berhubungan dan mempengaruhi satu sama lain untuk mencapai suatu tujuan atau sasaran yang telah ditetapkan.

\section{B. Weighted Product (WP)}

Menurut BEM PNJ Evaluasi Dosen Oleh Mahasiswa (EDOM) adalah bentuk evaluasi dari mahasiswa kepada dosen yang mengajar pada semester yang bersangkutan. Menurut website Universitas Indonesia, Evaluasi Dosen Oleh Mahasiswa adalah instrumen untuk menilai kinerja dosen dalam proses pembelajaran di akhir semester. Dengan mengisi EDOM berarti mahasiswa telah berpartisipasi untuk membantu meningkatkan mutu pembelajaran. EDOM bermanfaat bagi dosen untuk memperbaiki diri bila memang masih terdapat kekurangan serta mengembangkan potensi dan kelebihan yang dimilikinya. Bagi manajemen Universitas, fakultas, dan departemen (program studi), hasil EDOM dapat dijadikan acuan dalam menyusun program peningkatan mutu proses pembelajaran dan kinerja dosen. Dan yang terpenting bagi mahasiswa, dapat merasakan peningkatan mutu proses pembelajaran yang terus menerus.

Sehingga dapat disimpulkan bahwa EDOM adalah bentuk penilaian yang dilakukan mahasiswa kepada dosen yang mengajar di akhir semester untuk meningkatkan mutu proses pembelajaran.

\section{Metode Technology Acceptance Model}

Technology Acceptance Model (TAM), yang diperkenalkan oleh Davis pada tahun 1989 adalah suatu adaptasi dari Theory of Reasoned Action (TRA) yang dikhususkan untuk memodelkan penerimaan pemakai (user acceptance) terhadap teknologi. Model ini memiliki tujuan untuk menjelaskan faktor-faktor kunci dari perilaku pengguna teknologi informasi terhadap penerimaan pengadopsian teknologi informasi tersebut. TAM berteori bahwa niat seseorang untuk menggunakan sistem atau teknologi ditentukan oleh dua faktor, yaitu persepsi kemanfaatan (perceived usefulness), adalah tingkat kepercayaan individu bahwa penggunaan teknologi akan meningkatkan kinerjanya, dan persepsi kemudahan penggunaan (perceived ease of use), adalah tingkat kepercayaan individu bahwa penggunaan teknologi membuatnya lebih mudah menyelesaikan pekerjaan [5].

Tujuan utama dari Technology Acceptance Model (TAM) sesungguhnya adalah untuk memberikan dasar langkah dari dampak suatu faktor eksternal pada kepercayaan intern (internal beliefs), sikap (attitude) dan niat (intention). TAM dirancang untuk mencapai tujuan tersebut dengan cara mengidentifikasi beberapa variabel dasar yang disarankan pada penelitian sebelumnya yang setuju dengan faktor-faktor yang mempengaruhi secara cognitif dan affectif pada penerimaan komputer (computer acceptance) dan menggunakan TRA sebagai dasar teoritikal untuk menentukan model hubungan variabel penelitian. TAM memposisikan dua kepercayaan (beliefs), yaitu perceive usefulness dan perceived ease of use sebagai faktor utama perilaku penerimaan komputer.

Dalam metode Technology Acceptance Model (TAM) dikenal ada 5 konstruk [6], seperti terlihat pada Gambar 1, yaitu:

1. Persepsi kemudahan penggunaan (perceived ease of use), didefinisikan sebagai sejauh mana seorang percaya bahwa menggunakan suatu teknologi akan bebas dari usaha.

2. Persepsi kegunaan (perceived usefulness), didefinisikan sebagai sejauh mana seorang percaya bahwa menggunakan suatu teknologi akan meningkatkan kinerjanya.

3. Sikap terhadap penggunaan teknologi (attitude toward using), didefinisikan sebagai evaluasi dari pemakai tentang ketertarikannya dalam menggunakan teknologi.

4. Minat perilaku menggunakan teknologi (behavioral intention to use), didefinisikan sebagai minat (keinginan) seseorang untuk melakukan perilaku tertentu.

5. Penggunaan teknologi sesungguhnya (actual technology usage), diukur dengan jumlah waktu yang digunakan untuk berinteraksi dengan teknologi dan frekuensi penggunaan teknologi. 


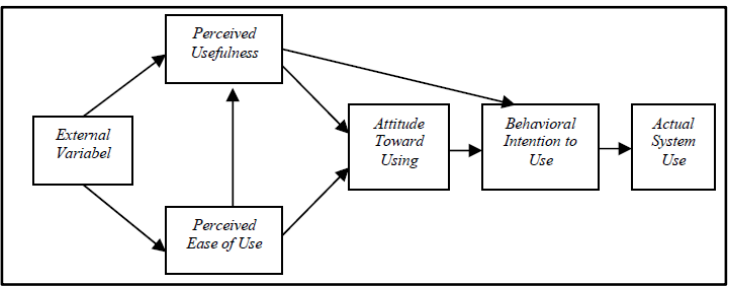

III. METODOLOGI PENELITIAN

\section{A. Lokasi dan Populasi Penelitian}

Lokasi penelitian ini dilakukan di Politeknik Negeri Jakarta. Responden yang berpartisipasi dalam penelitian ini adalah seluruh mahasiswa aktif PNJ yang dapat dipastikan menggunakan sistem Evaluasi Dosen Oleh Mahasiswa (EDOM) di portal website PNJ, karena sebagai salah satu syarat untuk mengambil marksheet. Waktu penelitian ini dilakukan selama bulan April sampai dengan Mei 2017.

\section{B. Metode Pengumpulan Data}

Sumber data untuk penelitian ini adalah sumber data primer, berupa jawaban responden terhadap pernyataan dalam kuesioner, untuk sampel mahasiswa akan ditentukan dengan teknik purposive sampling yaitu teknik penentuan sampel berdasarkan pertimbangan tertentu.

\section{Variabel yang Diteliti dan Operasional Variabel}

Penelitian ini menggunakan 3 variabel, diantaranya : Kebermanfaatan (Perceived Usefulness) sebagai variabel bebas pertama (X1), kemudahan (Perceived Ease of Use) sebagai variabel bebas kedua (X2), dan penerimaan mahasiswa terhadap sistem EDOM PNJ sebagai variabel terkait (Y) dimana menurut teori TAM secara signifikan variabel kebermanfaatan dan variabel kemudahan berpengaruh dalam penggunaan sistem EDOM PNJ.

\section{Teknik Analisis Data}

Uji Prasyarat (instrument) dilakukan dengan menggunakan uji validitas data dan uji reabilitas data. Uji prasyarat ini dilakukan dengan menggunakn program SPSS for Windows.

\section{(1) Uji Validitas}

Pengujian validitas dilakukan untuk mengetahui apakah semua pertanyaan (instrumen) penelitian yang diajukan untuk mengukur variabel penelitian adalah valid. Uji validitas dilakukan dengan melihat nilai signifikan masing-masing instrumen. Untuk menghitung nilai korelasi antara data pada masing-masing pertanyaan dengan skor total memakai rumus teknik korelasi product moment, dengan rumus sebagai berikut :

\author{
$(\Sigma[\mathrm{XY})]-(\operatorname{SX\Sigma }[\mathbf{Y})]$$$
r=\frac{\sqrt{\left[\mathrm{n} \Sigma \mathrm{X}^{2}-\left(\Sigma[\mathrm{X})^{2}\right]\left[\mathrm{n} \Sigma \mathrm{Y}^{2} \mathrm{I}(\Sigma \mathrm{KY} \mathrm{Y})^{2}\right] \mathbf{I}\right.}}{}
$$ \\ Keterangan : \\ r : nilai korelasi \\ n : jumlah responden \\ $\mathrm{X} \quad$ :skor setiap item \\ $\mathrm{Y} \quad$ : skor total \\ $\mathrm{XY}$ : skor setiap item $\mathrm{x}$ skor total \\ $\Sigma Y^{2}$ : jumlah kuadrat skor total \\ $\Sigma X^{2}$ : jumlah kuadrat skor item \\ $(\Omega Y)^{2}:$ kuadrat jumlah skor total \\ $(\Sigma X)^{2}$ : kuadrat jumlah skor item
}

\section{(2) Uji Reabilitas}

Pengujian realibilitas digunakan untuk mengukur konsistensi jawaban responden. Kriteria pengujian dilakukan dengan menggunakan pengujian Cronbach Alpha (CA). Jika alat ukur telah valid, selanjutnya alat ukur tersebut diuji. Reabilitas adalah suatu nilai yang menunjukan konsistensi suatu alat pengukur dalam mengukur gejala yang sama. Teknik pengukuran reliabilitas yang digunakan adalah teknik Cronbach. Rumus yang digunakan adalah :

$$
r_{11}=\left(\frac{k}{k-1}\right)\left(\frac{\sum a_{p^{2}}}{\alpha_{t^{2}}}\right)
$$

Keterangan :

$\begin{array}{ll}\mathrm{r}_{11} & \text { : Reabilitas instrumen } \\ \mathrm{k} & \text { : Banyak butir pertanyaan } \\ \alpha_{\mathrm{t}}^{2} & \text { : Deviasi standar total } \\ \sum \alpha_{\mathrm{b}}{ }^{2} & \text { : Jumlah deviasi standar butir }\end{array}$

Untuk jumlah varians butir ditentukan dengan cara menentukan nilai varians tiap butir dengan menggunakan rumus berikut :

$$
\alpha^{2}=\frac{\sum X^{2}-\frac{\left(\sum X\right)^{2}}{n}}{n}
$$

Keterangan :

$\mathrm{N} \quad$ : Jumlah responden

$\mathrm{X}$ : Nilai skor yang dipilih dari butir pertanyaan

\section{ANALISIS DAN PEMBAHASAN}

Penelitian mengambil total sampel sebanyak 20 orang mahasiswa Politeknik Negeri Jakarta, 
khususnya dari Jurusan TIK. Penelitian dilakukan dengan teknik kuesioner.

\section{A. Uji Validitas dan Reliabilitas Data}

Berdasarkan data yang diperoleh dari hasil kuesioner yang diberikan kepada responden yang masuk ke dalam sampel kemudian dilakukan pengujian terhadap kuesioner untuk mengukur tingkat kebaikan kuesioner yaitu dengan melakukan analisis validitas dan reliabilitas kuesioner. Validitas menunjukkan sejauh mana relevansi pertanyaan terhadap apa yang ditanyakan atau apa yang ingin diukur dalam penelitian. Tingkat validitas kuesioner diukur berdasarkan koefisien validitas yang dalam hal ini menggunakan koefisien korelasi Pearson, sedangkan realibilitas data untuk melihat sejauh mana kehandalan data tersebut berdasarkan koefisien Cronbach's alpha. Jika tampilan output pada kolom yang diuji (nilai r) diberi tanda bintang (flag), maka butir atau pertanyaan tersebut dinyatakan valid.

\section{1) Variable Perceived Ease of Use (PEU)}

Untuk uji validasi variable PEU (X2) hasilnya seperti tertera pada Tabel 1 .

TABEL 1. HASIL UJI VALIDASI VARIABEL PEU (X2)

\begin{tabular}{|c|l|r|}
\hline \multicolumn{3}{|c|}{ X2 - PEU } \\
\hline \multirow{3}{*}{$\begin{array}{c}\text { Pearson } \\
\text { Correlation }\end{array}$} & PEU1 & 0.793028129 \\
\cline { 2 - 3 } & PEU2 & 0.813772046 \\
\cline { 2 - 3 } & PEU3 & 0.66460329 \\
\cline { 2 - 3 } & PEU4 & 0.531570823 \\
\cline { 2 - 3 } & PEU5 & 0.829695978 \\
\hline & X2 - PEU & 1 \\
\hline $\mathrm{N}$ & \multicolumn{2}{|c}{20} \\
\hline
\end{tabular}

Pada Tabel 1 dapat dilihat bahwa semua item pernyataan bernilai lebih dari 0.468 (merupakan nilai r product dengan $\mathrm{N}=\mathrm{n}-2$, yaitu 18 ), berarti semua item tersebut dapat dinyatakan valid.

TABEL 2. HASIL UJI RELIABILITAS VARIABEL PEU (X2)

\begin{tabular}{|c|c|}
\hline Cronbach's Alpha & N of Items \\
\hline 0.754387536 & 5 \\
\hline
\end{tabular}

Sedangkan pengujian reliabilitas seluruh item yang digunakan dalam mengukur variabel PEU menghasilkan koefisien reliabilitas (cronbach's alpha) sebesar 0.754387536, seperti terlihat pada Tabel 2. Nilai koefisien reliabilitas ini lebih besar dari nilai patokan yakni sebesar 0.5 sehingga dapat dikatakan bahwa instrumen yang digunakan untuk mengukur variabel PEU tersebut dinyatakan memiliki reliabilitas yang tinggi. Dengan kata lain instrumen yang digunakan tersebut telah menunjukkan konsistensi pengukuran pada semua respondennya.
2) Variable Perceived Usefulness (PU)

Untuk uji validasi variable PU (X2) ditunjukkan pada Tabel 3.

\begin{tabular}{|c|c|c|}
\hline & \multicolumn{2}{|r|}{$\mathrm{X} 1-\mathrm{PU}$} \\
\hline \multirow{5}{*}{$\begin{array}{l}\text { Pearson } \\
\text { Correlation }\end{array}$} & PU1 & 0.645950054 \\
\hline & PU2 & 0.72041079 \\
\hline & PU3 & 0.796433889 \\
\hline & PU4 & 0.613025077 \\
\hline & X1 - PU & 1 \\
\hline $\mathrm{N}$ & & 20 \\
\hline
\end{tabular}

Pada Tabel 3 dapat dilihat bahwa semua item pernyataan bernilai lebih dari 0.468 (merupakan nilai $\mathrm{r}$ product dengan $\mathrm{N}=\mathrm{n}-2$, yaitu 18 ), berarti semua item tersebut dapat dinyatakan valid.

TABEL 4. HASIL UJI RELIABILITAS VARIABEL PU (X1)
\begin{tabular}{|l|l|}
\hline Cronbach's Alpha & N of Items \\
\hline 0.572143074 & 4 \\
\hline
\end{tabular}

Sedangkan pengujian reliabilitas seperti terlihat pada Tabel 4, seluruh item yang digunakan dalam mengukur variabel PU menghasilkan koefisien reliabilitas (cronbach's alpha) sebesar 0.572143074 . Nilai koefisien reliabilitas ini lebih besar dari nilai patokan yakni sebesar 0.5 sehingga dapat dikatakan bahwa instrumen yang digunakan untuk mengukur variabel PU tersebut dinyatakan memiliki reliabilitas yang tinggi. Dengan kata lain instrumen yang digunakan tersebut telah menunjukkan konsistensi pengukuran pada semua respondennya.

\section{3) Variable Attitude Toward of Using (ATU)}

Untuk uji validasi variable Y - ATU diperoleh :

\begin{tabular}{|c|c|c|}
\hline \multicolumn{3}{|r|}{$\mathrm{Y}-\mathrm{ATU}$} \\
\hline \multirow{4}{*}{$\begin{array}{l}\text { Pearson } \\
\text { Correlation }\end{array}$} & ATU1 & 0.848178476 \\
\hline & ATU2 & 0.86424554 \\
\hline & ATU3 & 0.866286373 \\
\hline & $\mathrm{Y}-\mathrm{ATU}$ & 1 \\
\hline $\mathrm{N}$ & & 20 \\
\hline
\end{tabular}

Pada Tabel 5 dapat dilihat bahwa semua item pernyataan bernilai lebih dari 0.468 (merupakan nilai r product dengan $\mathrm{N}=\mathrm{n}-2$, yaitu 18 ), berarti semua item tersebut dapat dinyatakan valid. 
TABEL 6. HASIL UJI RELIABILITAS VARIABEL Y - ATU.

\begin{tabular}{|l|l|}
\hline Cronbach's Alpha & N of Items \\
\hline 0.685240964 & 3 \\
\hline
\end{tabular}

Sedangkan pengujian reliabilitas seperti terlihat pada Tabel 6 , seluruh item yang digunakan dalam mengukur variabel ATU menghasilkan koefisien reliabilitas (cronbach's alpha) sebesar 0.685240964. Nilai koefisien reliabilitas ini lebih besar dari nilai patokan yakni sebesar 0.5 sehingga dapat dikatakan bahwa instrumen yang digunakan untuk mengukur variabel ATU tersebut dinyatakan memiliki reliabilitas yang tinggi. Dengan kata lain instrumen yang digunakan tersebut telah menunjukkan konsistensi pengukuran pada semua respondennya.

\section{4) Variable Behavioral Attitude Toward of Using} (ITU)

Untuk uji validasi variable Y - ITU diperoleh :

\begin{tabular}{|c|c|c|}
\hline & & Y - ITU \\
\hline \multirow{4}{*}{$\begin{array}{l}\text { Pearson } \\
\text { Correlation }\end{array}$} & ITU1 & 0.870503597 \\
\hline & ITU2 & 0.620025311 \\
\hline & ITU3 & 0.925105307 \\
\hline & Y - ITU & 1 \\
\hline $\mathrm{N}$ & & 20 \\
\hline
\end{tabular}

Pada Tabel 7 dapat dilihat bahwa semua item pernyataan bernilai lebih dari 0.468 (merupakan nilai $\mathrm{r}$ product dengan $\mathrm{N}=\mathrm{n}-2$, yaitu 18 ), berarti semua item tersebut dapat dinyatakan valid.

TABEL 8. HASIL UJI RELIABILITAS VARIABEL Y - ITU.

\begin{tabular}{|c|c|}
\hline Cronbach's Alpha & N of Items \\
\hline 0.601518785 & 3 \\
\hline
\end{tabular}

Sedangkan pengujian reliabilitas seperti pada Tabel 8, seluruh item yang digunakan dalam mengukur variabel ITU menghasilkan koefisien reliabilitas (cronbach's alpha) sebesar 0.601518785 . Nilai koefisien reliabilitas ini lebih besar dari nilai patokan yakni sebesar 0.5 sehingga dapat dikatakan bahwa instrumen yang digunakan untuk mengukur variabel ITU tersebut dinyatakan memiliki reliabilitas yang tinggi. Dengan kata lain instrumen yang digunakan tersebut telah menunjukkan konsistensi pengukuran pada semua respondennya.

\section{A. Kesimpulan}

\section{KESIMPULAN DAN SARAN}

Berdasarkan uraian di atas hasil yang dicapai pada penelitian yang dilakukan. Maka dapat disimpulkan hal-hal berikut:

1. Deskripsi Responden

Responden pada penelitian ini adalah 20 orang mahasiswa yang statusnya masih aktif di dalam perkuliahan di Politeknik Negeri Jakarta.

2. Uji Validitas dan Uji Relibilitas

Pada pengujian yang dilakukan dari olah data responden, terhadap pengujian validitas bahwa untuk semua variabel yang ada dinyatakan valid, dikarenakan rhitung $>$ rproduct.

\section{B. Saran}

Beberapa saran yang diajukan untuk penelitian berikutnya adalah:

1. Penelitian yang dilakukan pada rentang waktu tertentu, mengabaikan perilaku user yang intensitasnya berbeda dari saat-saat tertentu, dikarenakan keterbatasan waktu penelitian. Penelitian selanjutnya disarankan untuk melakukan longitudinal research dengan menggunakan data pada beberapa jangka waktu. Diharapkan dengan kurun waktu penelitian yang relatif panjang akan mendapatkan gambaran lebih lengkap mengenai penilaian mahasiswa terhadap sistem EDOM Politeknik Negeri Jakarta.

2. Penelitian yang dilakukan hanya sebatas pada perspektif mahasiswa dari jurusan Teknik Informatika dan Komputer, penelitian selanjutnya disarankan untuk meneliti secara keseluruhan mahasiswa di kampus Politeknik Negeri Jakarta.

\section{REFERENSI}

[1] Sutarman. 2009. Pengantar Teknologi Informasi. Jakarta: Sinar Grafika.

[2] Jogiyanto.2009. Analisis dan Desain Sistem Informasi.Yogyakarta: Andi

[3] Sayekti, Fran. Penerapan Technology Acceptance Model (Tam) dalam Pengujian Model Penerimaan Sistem Informasi Keuangan Daerah. Jurnal Manajemen Teori dan Terapan Tahun 9. No. 3, Desember 2016.

[4] Gaol, L, Jimmy. 2008. Sistem Informasi Manajemen Pemahaman dan Aplikasi. Jakarta: Penerbit PT Grasindo.

[5] Vankatesh, V. Morris et.al. 2003. User Acceptance of Information Technology: Towarda Unified View, Miss Quartely.

[6] Davis, F.D. 1986. Technology Acceptance Model for Empirically Testing New End-User Information Systems Theory and Results; Unpublished Doctoral Dissertation MIT. 